\title{
PEMANFAATAN TEPUNG TAPIOKA DENGAN DOSIS BERBEDA SEBAGAI SUMBER KARBON PEMBENTUK BIOFLOK PADA MEDIA PEMELIHARAAN BENIH IKAN PATIN (PANGASIUS SP.)
}

\section{The Utilization of Different Dose of Tapioca Flour as Carbon Source in Biofloc Rearing Media of Catfish Fry (Pangasius sp.)}

\author{
Novi Mayang Runa ${ }^{1}$, Mirna Fitrani ${ }^{1 *}$, dan Ferdinand Hukama Taqwa ${ }^{1}$ \\ ${ }^{1}$ Program Studi Akuakultur, Fakultas Pertanian Universitas Sriwijaya, Palembang \\ *fitranimirna@gmail.com
}

\begin{abstract}
Abstrak
Teknologi bioflok merupakan salah satu alternatif yang dapat digunakan pembudidaya untuk pengelolaan kualitas air media budidaya dengan memanfaatkan bakteri heterotrof dengan melakukan penambahan unsur karbon organik. Penelitian ini bertujuan untuk mengetahui pengaruh pemberian tepung tapioka sebagai sumber karbon bioflok pada pemeliharaan benih ikan patin terhadap kualitas air media pemeliharaan, kelangsungan hidup dan pertumbuhan benih ikan patin. Penelitian telah dilaksanakan pada bulan Februari sampai Maret 2015 di Laboratorium Budidaya Perairan, Program studi Akuakultur, Fakultas Pertanian Universitas Sriwijaya.Metode penelitian menggunakan Rancangan Acak Lengkap dengan empat perlakuan dan tiga ulangan. Pemberian karbon berupa dosis tepung tapioka menggunakan rasio C/N 5, 10 dan 15. Hasil penelitian diketahui bahwa pemberian tepung tapioka sebagai sumber karbon dengan rasio $\mathrm{C} / \mathrm{N} 15$ merupakan perlakuan terbaik dengan persentase rata-rata kelangsungan hidup benih ikan patin sebesar $88 \%$, pertumbuhan panjang mutlak sebesar 3,20 cm dan pertumbuhan berat mutlak 2,26 g.
\end{abstract}

Kata kunci: bioflok, benih ikan patin, tepung tapioka, rasio $\mathrm{C} / \mathrm{N}$

\begin{abstract}
Biofloc technology is one of alternative method that used to control water quality on culture media using heterotrophic bacteria with addition of organic matter. This research was held to determine the effect of tapioca flour addition as source of biofloc carbon in culture media on water quality, survival rate and growth of catfish fry. The research held on February to March 2015 in Laboratorium Budidaya Perairan, Aquaculture Department, Agriculture Faculty of Sriwijaya University. Used completely randomized design with four treatments and three replications were addition of tapioca flour with $\mathrm{C} / \mathrm{N}$ ration 5,10 , and 15 as carbon source. The result showed that addition of flour as carbon source with $\mathrm{C} / \mathrm{N}$ ratio of 15 was the best treatment with $88 \%$ survival rate, absolute length $3,20 \mathrm{~cm}$ and absolute weight 2,26 g.
\end{abstract}

Keywords : biofloc, catfish fry, tapioca flour, $\mathrm{C} / \mathrm{N}$ ratio

\section{PENDAHULUAN}

Ikan patin (Pangasius sp.) merupakan salah satu komoditas perikanan yang berpeluang dikembangkan untuk meningkatkan perekonomian masyarakat, sehingga pelaksanaan kegiatan budidaya ikan patin harus dilaksanakan secara efektif dan efisien melalui penerapan teknologi yang tepat. Saat ini pembangunan bidang perikanan secara global sangat bertumpu pada sektor perikanan budidaya air tawar, payau maupun laut setelah produksi perikanan tangkapan mengalami penuruan (Rohmana, 2009).
Teknologi bioflok merupakan salah satu teknologi dalam akuakultur yang bertujuan untuk memperbaiki kualitas air dan meningkatkan efisiensi pamanfaatan nutrien. Teknologi ini didasarkan pada konversi nitrogen anorganik terutama amonia oleh bakteri heterotrof menjadi biomassa mikroba yang kemudian dapat dikonsumsi oleh organisme budidaya (Ekasari, 2009).

Pada kondisi $\mathrm{C}$ dan $\mathrm{N}$ yang seimbang dalam air, bakteri heterotrof akan memanfaatkan N, baik dalam bentuk organik maupun anorganik untuk pembentukan biomassa sehingga konsentrasi $\mathrm{N}$ dalam air 
menjadi berkurang (de Schryver et al., dalam Ekasari, 2009).

Goldman (1987) dalam Ekasari (2009) menyatakan bahwa pada substrat dengan rasio $\mathrm{C} / \mathrm{N}$ sama dengan atau lebih dari 10 , bakteri heterotrof tidak akan meregenerasi amonia dari hasil katabolisme bahan organik (asam amino) dan sebaliknya akan memanfaatkannya untuk membentuk sel baru. Sebaliknya, pada rasio $\mathrm{C} / \mathrm{N}$ yang rendah $(<1,5)$ maka bakteri heterotrof akan melepaskan amonia ke lingkungannya (Hargeaves, 2006 dalam Ekasari, 2009). Avnilmelech (1999) menyatakan bahwa untuk aplikasi bioflok, rasio $\mathrm{C} / \mathrm{N}$ diupayakan mencapai 10 atau lebih.

Beberapa penelitian yang mengkaji teknologi bioflok pada budidaya antara lain benih ikan patin (Najamuddin, 2008), udang windu (Gunarto et al., 2010), benih ikan nila (Fransiska, 2014), ikan bandeng (Usman, 2012) dan udang vaname (Azhar, 2013). Teknologi bioflok membutuhkan sumber karbon sebagai pembentuk bioflok. Salah satu sumber karbon yang dapat digunakan adalah tepung tapioka.

Menurut hasil penelitian Gunarto et al., 2010, penggunaan tepung tapioka yang ditebar pada tambak udang vaname tradisional plus sebanyak $40 \%$ dari total pakan per hari memberikan dampak positif terhadap peningkatan sintasan dan produksi udang hasil panen. Pemanfaatan tepung tapioka sebagai sumber karbon untuk bioflok belum pernah digunakan pada ikan patin, sehingga perlu dilakukan kajian tepung tapioka sebagai agen nutrien dalam aplikasi bioflok pada ikan patin.

\section{BAHAN DAN METODE}

Bahan-bahan yang digunakan dalam penelitian meliputi benih ikan patin, tepung tapioka, probiotik, garam, kapur dolomite dan pakan. Alat-alat yang digunakan dalam pelaksanaan penelitian meliputi aku-

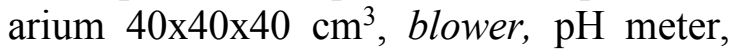
DO meter, termometer, dan timbangan digital. Penelitian ini dilaksanakan di Laboratorium Budidaya Perairan, Program Studi Akuakultur, Fakultas Pertanian, Universi- tas Sriwijaya, Indralaya pada bulan Februari-Maret 2015.

\section{Rancangan Percobaan}

Penelitian ini menggunakan Rancangan Acak Lengkap (RAL) yang terdiri dari empat perlakuan dengan tiga ulangan. Perlakuan pemberian tepung tapioka sebagai sumber karbon dalam penelitian adalah sebagai berikut :

$\mathrm{P} 0=$ Tanpa pemberian tepung tapioka

$\mathrm{P} 1$ = Pemberian tepung tapioka dengan rasio $\mathrm{C} / \mathrm{N} 5$

$\mathrm{P} 2$ = Pemberian tepung tapioka dengan rasio $\mathrm{C} / \mathrm{N} 10$

P3 = Pemberian tepung tapioka dengan rasio $\mathrm{C} / \mathrm{N} 15$

\section{Cara Kerja}

\section{Persiapan Penelitian}

Persiapan penelitian dimulai dari persiapan air, wadah pemeliharaan dan persiapan media. Air yang digunakan ditampung dahulu di bak penampungan untuk diendapkan. Wadah pemeliharaan berupa akuarium ukuran $40 \times 40 \times 40 \mathrm{~m}^{3}$ terlebih dahulu direndam dengan larutan kalium permanganat sebanyak $10 \mathrm{mg} . \mathrm{L}^{-1}$ selama 90 menit. Selanjutnya dicuci bersih dan dikeringkan. Air diisi dengan volume 30 L. Air yang sudah siap diberi aerasi.

Persiapan media dimulai dengan menambahkan kaporit ke air dengan dosis 30 g. $\mathrm{m}^{-3}$ dan ditunggu sampai bau kaporit hilang. Jika air yang telah diberi kaporit terdapat endapan maka endapan dibuang terlebih dahulu. Selanjutnya ditambahkan garam $3 \mathrm{~kg} . \mathrm{m}^{-3}$, dolomit $100 \mathrm{~g} . \mathrm{m}^{-3}$, tepung tapioka, probiotik $10 \mathrm{~mL} \cdot \mathrm{m}^{-3}$ dan air didiamkan selama 7 hari.

\section{Intensifikasi bakteri}

Bakteri yang digunakan adalah bakteri heterotrof (Bacillus subtilis, Bacillus lycheniformis dan Lactobacillus plantarum) dengan konsentrasi bakteri 1,0 x $10^{9}$ cfu. $\mathrm{mL}^{-1}$. Intensfikasi bakteri dilaksanakan pada awal masa pemeliharaan dengan pemberian sebanyak $10 \mathrm{~mL} . \mathrm{m}^{-3}$. Selanjutnya bak- 
teri ditambahkan setiap harinya pada sore hari.

\section{Prosedur pemberian karbon}

Pemberian karbon disesuaikan dengan rasio yang telah ditentukan yaitu rasio C/N 5, 10 dan 15. Pemberian karbon ke da- lam media pemeliharaan dilakukan setiap hari.Alur perhitungan pemberian tepung tapioka berdasarkan rasio $\mathrm{C} / \mathrm{N}$ yang telah ditentukan disajikan pada Gambar 1 (Najamuddin, 2008).

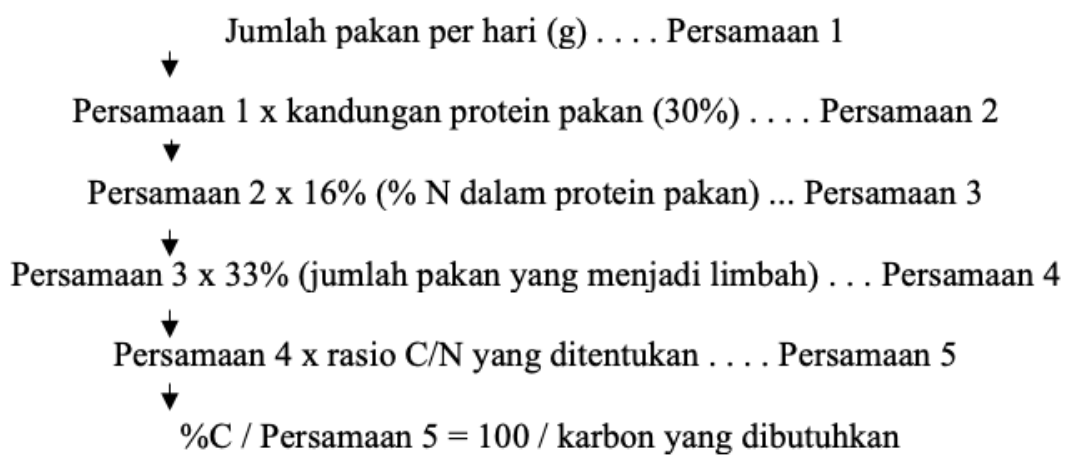

Gambar 1. Alur perhitungan pemberian tepung tapioca

Sebagai contoh apabila jumlah pakan yang diberikan sebanyak $1 \mathrm{~kg}$ dengan kandungan protein pakan sebesar 30\% dan kandungan karbon di dalam tepung tapioka sebesar 50\% (Suprapto dan Samtafsir, 2013), maka pemberian tepung tapioka untuk $1 \mathrm{~kg}$ pakan yaitu pada perlakuan dengan dosis rasio $\mathrm{C} / \mathrm{N} 5,10$ dan 15 secara berturut-turut adalah 158,40 g, 316,80 g dan 475,20 g. Pemberian tepung tapioka dilakukan setiap hari pada sore hari.

\section{Penebaran benih ikan}

Penebaran benih ikan dilaksanakan setelah satu minggu inokulasi bakteri. Benih yang ditebar berukuran panjang $3 \pm 0,5$ $\mathrm{cm}$ dengan padat tebar benih ikan patin sebanyak 150 ekor per akuarium. Aklimatisasi ikan dilakukan untuk meminimalisasi tingkat stres pada ikan.

\section{Pemeliharaan benih ikan}

Pemeliharaan benih ikan patin dilaksanakan selama 28 hari. Selama pemeliharaan dilaksanakan kegiatan pemberian pakan, pengontrolan ketinggian air, dan pengecekan ikan mati. Pemberian pakan dilakukan tiga kali setiap hari yaitu pagi, siang, dan sore secara at satiation untuk mengetahui jumlah pakan yang diberikan setiap hari sehingga dapat digunakan untuk menentukan dosis tepung tapioka yang akan diberikan ke dalam wadah pemeliharaan. Perhitungan berat tubuh dilakukan pada awal dan akhir pemeliharaan dengan menggunakan metode sampling dengan jumlah sampel 10 ekor setiap unit media uji. Pakan yang digunakan berupa pakan apung dengan kandungan protein $30 \%$.

Pengontrolan ketinggian air dan ikan mati dilakukan setiap hari. Penambahan air dilakukan jika ketinggian air mulai berkurang. Air media akan berkurang karena evaporasi akibat penerapan sistem aerasi dengan tekanan tinggi. Jika terdapat ikan mati, ikan tersebut akan diambil dari media uji, selanjutnya dilakukan pengukuran panjang dan berat sebagai data ikan mati. Pada akhir pemeliharaan, perhitungan jumlah, panjang dan berat tubuh ikan dilakukan untuk mendapatkan data akhir pemeliharaan benih ikan patin.

\section{Parameter Penelitian}

\section{Pertumbuhan berat mutlak}

Menurut rumus Effendie (2002), sebagai berikut :

$$
\mathrm{W}=\mathrm{W}_{\mathrm{t}}-\mathrm{W}_{\mathrm{o}}
$$

Keterangan :

$\mathrm{W}=$ Pertumbuhan berat mutlak benih ikan yang dipelihara $(\mathrm{g})$

$\mathrm{W}_{\mathrm{t}}=$ Berat benih ikan pada akhir pemeliharaan $(\mathrm{g})$

$\mathrm{W}_{\mathrm{o}}=$ Berat benih ikan pada awal pemeliharaan $(\mathrm{g})$ 
Pertumbuhan panjang mutlak

Menurut rumus Effendie (2002), sebagai berikut :

$$
\mathrm{L}=\mathrm{L}_{\mathrm{t}}-\mathrm{L}_{\mathrm{o}}
$$

Keterangan :

$\mathrm{L}=$ Pertumbuhan panjang mutlak benih ikan yang dipelihara $(\mathrm{cm})$

$\mathrm{L}_{\mathrm{t}}=$ Panjang benih ikan pada akhir pemeliharaan $(\mathrm{cm})$

$\mathrm{L}_{\mathrm{o}}=$ Panjang benih ikan pada awal pemeliharaan (cm)

\section{Kelangsungan hidup}

Pengukuran kelangsungan hidup benih ikan dilakukan dengan membandingkan jumlah ikan hidup pada akhir pemeliharaan dengan jumlah pada awal penebaran. Rumus yang digunakan untuk menghitung kelangsungan hidup menurut Effendie (2002) sebagai berikut :

$$
\mathrm{KH}=\frac{\mathrm{Nt}}{\mathrm{No}} \times 100 \%
$$

Keterangan :

$\mathrm{KH}=$ Kelangsungan hidup (\%)

$\mathrm{N}_{\mathrm{t}}=$ Jumlah benih ikan pada akhir pemeliharaan (ekor)

$\mathrm{N}_{\mathrm{o}}=$ Jumlah benih ikan pada awal pemeliharaan (ekor)

\section{Efisiensi Pakan (EP)}

Rumus yang digunakan untuk menghitung Efisiensi Pakan (EP) menurut Effendie (2002) adalah sebagai berikut :

Keterangan :

$$
\mathrm{EP}=\frac{(\mathrm{Wt}+\mathrm{D})-\mathrm{Wo}}{\mathrm{F}} \times 100 \%
$$

$\mathrm{EP}=$ Efisiensi pakan (\%)

$\mathrm{W}_{\mathrm{t}}=$ Berat benih ikan pada akhir pemeliharaan $(\mathrm{g})$
$\mathrm{W}_{\mathrm{o}}=$ Berat benih ikan pada awalpemeliharaan $(\mathrm{g})$

$\mathrm{D}=$ Berat benih ikan yang mati selama pemeliharaan (g)

$\mathrm{F}=$ Jumlah pakan yang diberikan $(\mathrm{g})$

\section{Kualitas air}

Parameter kualitas air yang diukur meliputi suhu, $\mathrm{pH}$, oksigen terlarut, amonia, nitrit, dan padatan tersuspensi total. Pengukuran suhu dan $\mathrm{pH}$ dilakukan setiap hari. Oksigen terlarut, amonia, nitrit dan kepadatan tersuspensi total diukur setiap satu minggu sekali.

\section{Analisis Data}

Data kelangsungan hidup, partumbuhan dan efisiensi pakan benih ikan patin diolah menggunakan analisis sidik ragam. Apabila terdapat pengaruh yang nyata maka dilakukan uji lanjut BNJ dengan taraf kepercayaan 95\% (Hanafiah, 2002). Parameter kualitas air dianalisis secara deskriptif berupa tabel.

\section{HASIL DAN PEMBAHASAN Kualitas Air}

Air merupakan media hidup bagi ikan yang akan berpengaruh pada kelangsungan hidup dan pertumbuhan ikan. Beberapa faktor yang perlu diperhatikan untuk kualitas air, kelangsungan hidup dan pertumbuhan benih ikan patin yang dipelihara menggunakan bioflok adalah suhu, $\mathrm{pH}$, oksigen terlarut, amonia, nitrit dan padatan tersuspensi total. Data pengukuran kualitas air dapat dilihat pada Tabel 1 sebagai

\begin{tabular}{|c|c|c|c|c|c|c|}
\hline Perlakuan & $\begin{array}{l}\text { Suhu } \\
\left({ }^{\circ} \mathrm{C}\right)\end{array}$ & $\mathrm{pH}$ & $\begin{array}{l}\text { Oksigen } \\
\text { Terlarut } \\
\left(m g . L^{-1}\right)\end{array}$ & $\begin{array}{l}\text { Amonia } \\
\left(\mathrm{mg} \cdot \mathrm{L}^{-1}\right)\end{array}$ & $\begin{array}{c}\text { Nitrit } \\
\left(\mathrm{mg} . \mathrm{L}^{-1}\right)\end{array}$ & $\begin{array}{c}\text { Padatan } \\
\text { Tersupensi } \\
\text { Total }\left(\text { mg.L } L^{-1}\right)\end{array}$ \\
\hline P0 & $25-31$ & $4,50-7,61$ & $7,22-8,87$ & $0,02-0,05$ & $0,005-0,009$ & $17,6-77,4$ \\
\hline P1 & $25-31$ & $4,74-7,75$ & $6,08-8,69$ & $0,02-0,03$ & $0,004-0,010$ & $13,2-100$ \\
\hline $\mathrm{P} 2$ & $25-31$ & $4,80-7,71$ & $6,18-8,84$ & $0,03-0,05$ & $0,003-0,007$ & $14,2-71,6$ \\
\hline P3 & $25-31$ & $4,63-7,68$ & $4,79-8,71$ & $0,03-0,04$ & 0,004-0,009 & $15,6-100$ \\
\hline
\end{tabular}
berikut :

Tabel 1. Kisaran kualitas air pemeliharaan benih ikan patin

Hasil pengukuran suhu selama penelitian berkisar $25-31{ }^{\circ} \mathrm{C}$ dan berada dalam batas yang layak bagi pertumbuhan benih ikan patin. Pada kisaran tertentu, suhu akan berpengaruh terhadap pembentukan flok. Menurut Crab et al. (2008), nilai suhu pada 
kisaran $20-25^{\circ} \mathrm{C}$ akan menghasilkan kondisi flok yang lebih stabil. Nilai $\mathrm{pH}$ selama penelitian mengalami penurunan. Hal ini diduga karena adanya proses nitrifikasi pada media pemeliharaan.

Pada budidaya intensif dibutuhkan oksigen terlarut yang cukup, karena konsentrasi yang terlalu rendah dapat mempengaruhi kesehatan ikan (Wedemeyer, 1996 dalam Rohmana, 2009). Hasil penelitian ini menunjukkan bahwa kadar oksigen terlarut memiliki nilai yang berbeda pada setiap perlakuan.

Pada perlakuan P0 tanpa pemberian tepung tapioka, kadar oksigen terlarut lebih besar daripada perlakuan lainnya, hal ini diduga karena pada perlakuan P1, P2 dan P3 ditambahkan bakteri heterotrof. Bakteri heterotrof ini memerlukan oksigen dalam penguraian bahan-bahan organik (feses, sisa pakan dan jasad renik yang mati).

Kadar amonia dan nitrit pada setiap perlakuan mengalami fluktuasi dikarenakan terjadinya perubahan suhu dan $\mathrm{pH}$ selama masa pemeliharaan. Saat suhu dan $\mathrm{pH}$ mengalami peningkatan maka akan berpengaruh terhadap aktivitas metabolisme benih ikan patin sehingga feses yang dihasilkan juga meningkat. Meningkatnya jumlah feses dalam wadah budidaya dapat berdampak terhadap jumlah amonia yang terbentuk. Pada perlakuan P1, P2 dan P3 penurunan kadar amonia dan nitrit diduga karena adanya pemberian tepung tapioka pada wadah pemeliharaan yang dimanfaatkan oleh bakteri heterotrof sebagai sumber karbon sehingga bakteri tersebut dapat bekerja dalam mempercepat degradasi amonia dan nitrat.

Padatan tersuspensi total mengala-mi peningkatan pada semua perlakuan. Peningkatan pada perlakuan P1, P2 dan P3 ini terjadi karena adanya pemberian tepung tapioka pada wadah budidaya yang dilakukan setiap hari dan juga berdampak pada semakin banyaknya bioflok yang dihasilkan. Sedangkan pada perlakuan P0 padatan tersuspensi total tinggi diduga karena adanya sisa metabolisme benih ikan patin dan pakan yang tidak termakan serta tidak dilakukan penyiponan selama penelitian.

Avnimelech (1999) menyatakan bahwa produksi bakteri heterotrof dapat ditingkatkan melalui penambahan karbon ke dalam media budidaya. Menurut Effendi (2003) menjelaskan bahwa padatan tarsuspensi total tidak bersifat toksik bagi organisme air, tetapi tingginya nilai tersebut dapat menghambat penetrasi cahaya ke dalam air.

\section{Kelangsungan Hidup}

Kelangsungan hidup benih ikan patin selama pemeliharaan menunjukkan bahwa pada perlakuan P3 memberikan hasil terbaik yaitu $88 \%$. Kelangsungan hidup benih ikan patin selama pemeliharaan disajikan pada Tabel 2.

Tabel 2. Kelangsungan hidup benih ikan patin selama penelitian

\begin{tabular}{cc}
\hline Perlakuan & $\begin{array}{r}\text { Kelangsungan Hidup (\%) } \\
\left(\mathrm{BNJ}_{0,05}=5,54\right)\end{array}$ \\
\hline P0 & $34,00^{\mathrm{a}}$ \\
P1 & $70,00^{\mathrm{b}}$ \\
P2 & $70,89^{\mathrm{b}}$ \\
P3 & $88,00^{\mathrm{c}}$ \\
\hline
\end{tabular}

Keterangan : Angka-angka yang diikuti oleh huruf superscript yang berbeda menunjukkan perbedaan yang nyata pada uji taraf kritis 5\%

Hasil uji BNJ pada Tabel 2 menunjukkan bahwa kelangsungan hidup ikan patin terbaik pada perlakuan P3. Pada perlakuan P1 kelangsungan hidupnya tidak berbeda nyata dengan perlakuan P2 namun berbeda nyata dengan perlakuan P0.Hal ini dikarenakan adanya aktivitas bakteri heterotrof. Bakteri ini mampu memanipulasi kepadatan dan aktivitas mikroba sebagai salah satu cara mengontrol kualitas air 
dengan mentransformasikan amonium menjadi protein mikrobial agar mampu mengurangi residu dari sisa pakan (Avnimelech dan Kochba, 2009). Kelangsungan hidup benih ikan terendah ditunjukkan pada perlakuan $\mathrm{P} 0$ tanpa pemberian tepung tapioka. Kematian banyak terjadi memasuki minggu kedua dan ketiga pemeliharaan benih, hal ini disebabkan oleh hasil metabolisme yang dikeluarkan berupa karbondioksida dan amonia yang terakumulasi pada media penelitian.Amonia yang terakumulasi di dalam media pemeliharaan sangat berbahaya dan mampu memicu timbulnya racun yang dapat berdampak pada kematian benih ikan.

Dengan adanya pemberian sumber karbon bagi bioflok berupa tepung tapioka diharapkan dapat berpengaruh terhadap perombakan limbah budidaya oleh bakteri. Najamuddin (2008) menyatakan bahwa ikan masih bisa tumbuh pada konsentrasi amonia yang tinggi sebab hal ini tidak berlangsung lama karena adaya penambahan karbon ke dalam air untuk mempercepat degradasi amonia dan nitrit.

\section{Pertumbuhan Panjang dan Berat Mutlak}

Hasil uji BNJ pada Tabel 3 menunjukkan bahwa pertumbuhan panjang mutlak dan pertumbuhan berat mutlak benih ikan patin pada perlakuan $\mathrm{P} 1, \mathrm{P} 2$ dan $\mathrm{P} 3$ berbeda nyata dengan perlakuan P0 tanpa pemberian tepung tapioka. Dapat dilihat bahwa perlakuan terbaik ditunjukkan pada perlakuan $\mathrm{P} 3$ pemberian tepung tapioka dengan rasio $\mathrm{C} / \mathrm{N} 15$.

Hal ini diduga karena semakin banyak jumlah tepung tapioka yang diberikan ke dalam media pemeliharaan melalui peningkatan rasio $\mathrm{C} / \mathrm{N}$ maka pembentukan flok akan semakin baik. Menurut pendapat Avnimelech (1999), penambahan karbon dapat mereduksi nitrogen anorganik dalam media, sejalan dengan pendapat Crab et al, (2008) bahwa pertumbuhan bakteri heterotrof dipengaruhi oleh $\mathrm{C} / \mathrm{N}$ rasio.

Selain itu, bioflok dapat dijadikan sebagai sumber nutrisi atau pakan benih ikan selain pakan komersil sehingga pertumbuhan semakin baik. Pertumbuhan pada rasio $\mathrm{C} / \mathrm{N}$ yang lebih tinggi lebih cepat, dikarenakan semakin banyak jumlah karbon yang ditambahkan maka kerja bakteri semakin bagus sehingga bakteri dapat tumbuh dengan jumlah yang melimpah yang berguna sebagai pakan alami ikan.

Hasil pertumbuhan panjang mutlak dan pertumbuhan berat mutlak benih ikan patin pada tiap perlakuan mengalami peningkatan yang disajikan dalam Tabel 3 berikut :

Tabel 3. Pertumbuhan panjang mutlak dan pertumbuhan berat mutlak benih ikan patin

\begin{tabular}{ccc}
\hline Perlakuan & $\begin{array}{c}\text { Pertumbuhan Panjang } \\
\text { Mutlak }(\mathrm{cm}) \\
\left(\mathrm{BNJ}_{0,05}=0,28\right)\end{array}$ & $\begin{array}{c}\text { Pertumbuhan Berat } \\
\text { Mutlak }(\mathrm{g}) \\
\left(\mathrm{BNJ}_{0,05}=0,38\right)\end{array}$ \\
\hline P0 & $1,50^{\mathrm{a}}$ & $0,62^{\mathrm{a}}$ \\
P1 & $2,91^{\mathrm{b}}$ & $1,85^{\mathrm{b}}$ \\
P2 & $2,94^{\mathrm{b}}$ & $1,87^{\mathrm{b}}$ \\
P3 & $3,20^{\mathrm{c}}$ & $2,26^{\mathrm{c}}$
\end{tabular}

Keterangan : Angka-angka yang diikuti oleh huruf superscript yang berbeda menunjukkan perbedaan yang nyata pada uji taraf kritis 5\%

\section{Efisiensi Pakan}

Hasil uji BNJ menunjukkan bahwa efisiensi pakan selama pemeliharaan benih ikan patin dengan pemberian tepung tapioka yaitu perlakuan P1, P2 dan P3 memberikan hasil yang berbeda nyata dibandingan perlakuan P0 tanpa pemberian tepung tapioka. Hal ini diduga karena adanya penambahan bakteri heterotrof ke dalam media pemeliharaan yang mampu bekerja secara optimal dengan adanya pemberian tepung tapioka sebagai sumber karbon. 
Dengan adanya sumber karbon dalam hal ini tepung tapioka maka bakteri heterotrof mampu mengasimilasi sebagian besar karbon dan nitrogen anorganik menjadi protein mikroba yang berperan sebagai pakan alami benih ikan patin. Dengan tersedianya pakan alami, maka efisiensi pakan menjadi lebih tinggi (Najamuddin, 2008). Nilai efisiensi pakan benih ikan patin disajikan dalam tabel 4 sebagai berikut :

Tabel 4. Efisiensi pakan benih ikan patin

\begin{tabular}{cc}
\hline Perlakuan & $\begin{array}{c}\text { Efisiensi pakan }(\%) \\
\left(\mathrm{BNJ}_{0,05}=24,45\right)\end{array}$ \\
\hline P0 & $27,41^{\mathrm{a}}$ \\
P1 & $121,83^{\mathrm{b}}$ \\
P2 & $123,58^{\mathrm{b}}$ \\
P3 & $146,05^{\mathrm{b}}$ \\
\hline
\end{tabular}

Keterangan : Angka-angka yang diikuti oleh huruf superscript yang berbeda menunjukkan perbedaan yang nyata pada uji taraf kritis 5\%

Bakteri heterotrof memerlukan sumber karbon dalam hal ini tepung tapioka. Bakteri heterotrof akan tumbuh maksimal melalui peningkatan rasio $\mathrm{C} / \mathrm{N}$ dengan penambahan sumber karbon organik secara kontinu seperti molase, tepung terigu dan tepung tapioka (Hari et al., 2004). Hal ini sependapat dengan Avnimelech (2006) bahwa secara umum rasio $\mathrm{C} / \mathrm{N}$ yang diinginkan dari suatu perairan adalah rasio $\mathrm{C} / \mathrm{N}>15$.

\section{KESIMPULAN DAN SARAN Kesimpulan}

Pemberian tepung tapioka pada perlakuan $\mathrm{P} 3$ dengan rasio $\mathrm{C} / \mathrm{N} 15$ sebagai sumber karbon bagi bioflok merupakan perlakuan terbaik karena dapat mempertahankan kualitas air media pemeliharaan, menghasilkan kelangsungan hidup, pertumbuhan benih ikan patin serta efisiensi pakan tinggi selama pemeliharaan.

\section{Saran}

Perlu dilakukan penelitian lebih lanjut untuk mencari dosis optimum dengan rasio $\mathrm{C} / \mathrm{N}>15$ melalui pemberian tepung tapioka dalam aplikasi bioflok pada pemeliharaan benih ikan patin.

\section{DAFTAR PUSTAKA}

Avnimelech Y. 1999. Carbon/nitrogen ratio as a control elemen in aquaculture system. J. Aquaculture. 176: 227235.

Avnimelech Y dan Kochba M. 2009. Evaluation of nitrogen uptake on excretion by Tilapia in biofloc tanks using ${ }^{15} \mathrm{~N}$ racing. J. Aquaculture. 287:163-168.

Azhar MH. 2013. Peranan Sumber Karbon Eksternal yang Berbeda dalam Pembentukan Bioflok dan Pengaruhnya Terhadap Kualitas Air serta Produksi pada Sistem Budidaya Udang Vaname Litopenaeus vannamei. Tesis S2 (Tidak dipublikasikan). Sekolah Pascasarjana Institut Pertanian Bogor, Bogor.

Crab R, De Schryver P, Defoirdt T, Boon N, dan Verstraete W. 2008. The basics of bio-flocs technology: The added value for aquaculture. $J$. Aquaculture. 277:125-137.

Effendi H. 2003. Telaah Kualitas Air. Kanisius, Yogyakarta.

Effendie MI. 2002. Biologi Perikanan. Yayasan Pustaka Nusantara, Yogyakarta.

Ekasari J. 2009. Teknologi bioflok: Teori dan aplikasi dalam perikanan budidaya sistem intensif. Jurnal Akuakultur Indonesia.8(2):117-126.

Fransiska MS. 2012. Aplikasi Teknologi Bioflok pada Pemeliharaan Benih Ikan Nila (Oreochromis niloticus). Tesis S2 (Tidak dipublikasikan). Pascasarjana Universitas Terbuka, Jakarta.

Gunarto, Muliani dan Abdul M. 2010.Pengaruh aplikasi sumber Ckarbohidrat (tepung tapioka) dan fermentasi probiotik pada budidaya udang windu, Panaeus monodon pola intensif di tambak. Jurnal Riset Akuakultur. 5(3):393-409. 
Hanafiah KA. 2002. Rancangan Percobaan: Teori dan Aplikasi. PT. Raja Grafindo Persada, Jakarta.

Hari B, Kurup BM, Varghese JT, Schrama JW dan Verdegem MCJ. 2004. Effect of carbohydrate addition on production in exstensive shrimp culture systems. J. Aquaculture. 241:179-194.

Najamuddin M. 2008. Pengaruh Penambahan Dosis Karbon yangBerbeda Terhadap Produksi Benih Ikan Patin (Pangasius sp.) pada Sistem Pendederan Intensif. Skripsi S1 (Tidak dipublikasikan). Fakultas Perikanan Ilmu Kelautan Institut Pertanian Bogor, Bogor.

Rohmana D. 2009. Konversi Limbah Budidaya Ikan Lele, Clarias sp. Menjadi Biomassa Bakteri Heterotrof untuk Perbaikan Kualitas Air dan Makanan Udang Galah, Macrobrachium rosenbergii. Tesis S2 (Tidak dipublikasikan). Sekolah Pascasarjana Institut Pertanian Bogor, Bogor.

Suprapto dan Samtafsir LS. 2013. Biofok 165 Rahasia Sukses Teknologi Budidaya Lele. Agro 165, Depok.

Usman. 2012. Konversi Limbah Nitrogen Budidaya Ikan Menjadi Bioflok dan Pemanfaatannya bagi Pertumbuhan Ikan Bandeng. Disertasi S3 (Tidak dipublikasikan). Sekolah Pascasarjana Institut Pertanian Bogor, Bogor. 